Classification: BIOLOGICAL SCIENCES, Biochemistry

Quantitative proteomics indicate a strong correlation of mitotic phospho-/dephosphorylation with non-

\title{
structured regions of substrates
}

6 Hiroya Yamazaki ${ }^{\text {a }}$, Hidetaka Kosako ${ }^{\text {b }}$, and Shige H. Yoshimura ${ }^{\text {a, }}$

${ }^{a}$ Graduate School of Biostudies, Kyoto University, Kyoto, Japan, ${ }^{b}$ Division of Cell Signaling, Fujii Memorial

Institute of Medical Sciences, Tokushima University, Tokushima, Japan.

9

$10{ }^{1}$ Corresponding author:

11 Shige H. Yoshimura

12 Laboratory of Plasma Membrane and Nuclear Signaling,

13 Graduate School of Biostudies, Kyoto University,

14 Yoshida Konoe, Sakyo-ku, Kyoto 606-8501, Japan

15 Tel \& Fax: +81-75-753-7906

16 E-mail: yoshimura@lif.kyoto-u.ac.jp

18 Keywords: phosphorylation, mitosis, intrinsically disordered region 


\section{Abstract}

21 Protein phosphorylation plays a critical role in the regulation and progression of mitosis. More than 10,000 phosphorylated residues and the associated kinases have been identified to date via proteomic analyses. Although some of these phosphosites are associated with regulation of either protein-protein interactions or the catalytic activity of the substrate protein, the roles of most mitotic phosphosites remain unclear. In this study, we examined structural properties of mitotic phosphosites and neighboring residues to understand the role of heavy phosphorylation in non-structured domains. Quantitative mass spectrometry analysis of mitosis-arrested and non-arrested HeLa cells revealed $>4,100$ and $>2,200$ residues either significantly phosphorylated or dephosphorylated, respectively, at mitotic entry. The calculated disorder scores of amino acid sequences of neighboring individual phosphosites revealed that $>70 \%$ of dephosphorylated phosphosites exist in disordered regions, whereas $50 \%$ of phosphorylated sites exist in non-structured domains. A clear inverse correlation was observed between probability of phosphorylation in non-structured domain and increment of phosphorylation in mitosis. These results indicate that at entry to mitosis, a significant number of phosphate groups are removed from non-structured domains and transferred to more-structured domains. Gene ontology term analysis revealed that mitosis-related proteins are heavily phosphorylated, whereas RNA-related proteins are both dephosphorylated and phosphorylated, suggesting that heavy phosphorylation/dephosphorylation in nonstructured domains of RNA-binding proteins plays a role in dynamic rearrangement of RNA-containing organelles, as well as other intracellular environments. 


\section{Significance Statement}

41 Progression of mitosis is tightly regulated by protein phosphorylation/dephosphorylation. Although proteomic

42 studies have identified tens of thousands of phosphosites in mitotic cells, the roles of them remain to be

43 answered. We approached this question from the viewpoint of the higher-order structure of phosphosites.

44 Quantitative proteomics and bioinformatic analyses revealed that more than $70 \%$ of mitotic dephosphorylation events occurred in non-structured regions. Non-structured regions of cellular proteins are attracting considerable attention in terms of their involvement in dynamic rearrangements of intracellular membrane-less organelles and protein assembly/disassembly processes. Our results suggest the possibility that a vast amount of mitosisassociated dephosphorylation/phosphorylation at non-structured regions plays a role in regulating the dynamic assembly/disassembly of intracellular architectures and organelles such as chromosomes and nucleolus. 


\section{Introduction}

Protein phosphorylation/dephosphorylation plays a critical role in a number of cellular processes, such as intracellular signaling, cell cycle regulation, and mitosis. Studies using mass spectrometry have identified tens of thousands of phosphorylation sites, resulting in the creation of an atlas of phosphorylation states and dynamic alterations in phosphorylation during the cell cycle (1), mitosis (2-4), and cell differentiation and development $(3,4)$.

A variety of structural biological approaches have been used to elucidate the effect of phosphorylation on the structure/function of substrate proteins. The addition of a phosphate group to the hydroxyl group of a target residue (Ser, Thr, or Tyr) can affect i) interactions with other proteins, ii) access of substrate molecules to the catalytic center of the enzyme, or iii) local internal energy, which can exert allosteric effects on other parts of the protein. Phosphorylation significantly affects stereo-specific interactions between the substrate and other molecules, thus ensuring tight regulation of biological reactions.

Recent bioinformatics studies revealed that phosphorylation occurs preferentially on residues in intrinsically disordered regions (IDRs) of proteins (5-7). Due to the absence of secondary and tertiary structures, IDRs are thought to function as flexible substrates for both phosphorylation and other post-translational modifications (6). Although the structural and functional significance of IDR phosphorylation remains to be fully elucidated, several possibilities have been proposed. For example, the addition of a phosphate group could reduce the flexibility of the IDR, thus facilitating specific interactions. Phosphorylation of a serine residue in the IDR of the transcription factor Ets1 alters the structure of the IDR and reduces the affinity of Ets1 for DNA (8). Phosphorylation of Ser19 in the IDR of the regulatory light chain of smooth muscle myosin induces the formation of an $\alpha$-helix that activates an actin-dependent ATPase (9-11).

Another possible role for phosphorylation of IDRs could be to reduce the stereo-specificity between kinases and substrates. The human genome encodes $\sim 520$ different kinases and $\sim 150$ phosphatases, which 
phosphorylate and dephosphorylate, respectively, more than 40,000 sites in more than 10,000 proteins $(12,13)$.

A single kinase (or phosphatase) can therefore phosphorylate (or dephosphorylate) many different substrates.

Indeed, bioinformatic and biochemical studies have identified only weak consensus sequences for individual

kinases (14) and almost no consensus around the target residues of phosphatases. The presence of a target residue in an IDR reduces the stereo-specificity of the enzyme-substrate interaction, thus enabling multiple enzyme-substrate combinations.

Mitosis is a critical cellular process tightly regulated by phosphorylation. Several thousand protein

residues are known to be phosphorylated upon entry to mitosis $(1,2)$. A number of mitosis-associated kinases have been identified, including CDK1, Aurora kinase, Plk1, Bub1, and Haspin (reviewed in [17-21]). different phosphosites are known to be dephosphorylated during anaphase (22), and more than 500 are dephosphorylated upon entry to mitosis (2). For example, CDK1 is activated via dephosphorylation by vast number of phosphate groups are transferred to and from substrate proteins in the early phase of mitosis. how such a vast number of phosphate groups are transferred between different sets of proteins and whether these different mitosis-associated phosphosites differ structurally. Determining the distribution of phosphosites among structured and non-structured regions of substrate proteins is particularly important in terms of understanding the structural effects of phosphorylation/dephosphorylation. In this study, we therefore performed a phosphoproteomic analysis of cellular proteins to both quantify and compare individual phosphosites in mitosis and interphase. We also analyzed the structural properties (i.e., IDR or structured) of those sites. Our analysis of more than 6,000 phosphosites revealed a clear relationship between mitotic 


\section{Results}

\section{Quantitative proteomic analysis of phosphoproteins in mitosis}

100 A comparative proteomics analysis was performed to examine phosphopeptides obtained from asynchronous and mitotic HeLa cells. Tryptic peptides from the two cell populations were labeled with tandem mass tag (TMT) reagents. LC-MS/MS analysis was performed after enrichment of phosphopeptides using $\mathrm{TiO}_{2}$. In total, 17,003 phosphopeptides were quantified (Fig. 1A), 15,368 of which were assigned to 3,701 proteins based on database searching. For quantitative analysis of phosphorylation, peptides with only a single phosphosite were extracted and assigned a mitotic abundance ratio, which provides an indication of enrichment in the specific phosphosite in mitosis relative to interphase ( $\log _{2}[\mathrm{M}$ phase/asynchronous $\left.]\right)$. For phosphosites detected in more than two different peptides, the abundance ratio for each peptide was averaged. As a result, a total of 10,255 phosphorylation sites were quantified and subjected to further analyses, whereas 4,400 sites were detected only in peptides with multiple phosphosites. Of 10,255 phosphorylation sites, 9,656 were already registered in the PhophoSitePlus phosphoprotein database (25); thus, our dataset contained $\approx 600$ previously unreported phosphosites.

To extract phosphosites specifically up- or down-regulated during mitosis, the p-values for individual

113 peptides were plotted versus mitotic abundance. For a p-value threshold of 0.01 (Fig. 1A), two different phosphosite populations were extracted, one positive in terms of mitotic abundance (UP group) and the other negative (DOWN group) (Fig. 1B, Table S2). The UP group included 4,138 phosphosites distributed among 1,955 proteins, and the DOWN group included 2,249 phosphosites among 1,372 proteins. A significant number of proteins (686) contained both UP and DOWN sites (Fig. 1C). A small peak found at $\approx 2.4$ (mitotic abundance ratio) (Fig. 1B) corresponded primarily to linker domains of $\mathrm{C}_{2} \mathrm{H}_{2}$ zinc finger proteins, which are known to be phosphorylated during mitosis (26). Several mitotic phosphosites known to be up-regulated during mitosis, such 
as S11 and S29 of histone H3.1 (27) and T161 of CDK1 (24), were identified in the UP group, with abundance ratios of 2.4, 1.3, and 0.8 , respectively. Phosphosite T14 of CDK1, known to be down-regulated during mitosis (24), was detected in the DOWN group, with a mitotic abundance of -0.7 . Gene ontology (GO) analysis was performed for the UP and DOWN sites. Using DAVID, we obtained biological process terms $(28,29)$ and evaluated GO term enrichment in each group by dividing the number of proteins by the total number of proteins associated with specific GO terms (Fig. 1D). As expected, the UP sites were highly enriched in proteins related to mitotic chromosomes. Interestingly, both UP and DOWN sites were highly enriched in proteins related to RNA processing and splicing, suggesting that RNA-related proteins are regulated by both phosphorylation and dephosphorylation during mitosis (see Discussion section). A larger number of UP sites than DOWN sites does not necessarily mean that there is a greater amount of phosphorylated proteins than dephosphorylated proteins in a mitotic cell. To examine this issue further, the phosphorylated proteins in cells in interphase and mitosis were quantified by dot-blot analysis using pIMAGO (30). Careful quantification revealed that $5.4 \mathrm{fmol}$ of phosphate groups were attached to proteins in a single mitotic cell, versus $3.8 \mathrm{fmol}$ in an asynchronous cell. These values correspond to 4.7 and $3.3 \mathrm{mM}$ in the mitotic and asynchronous cells, respectively (the volume of a HeLa cell is reportedly $1.16 \mathrm{pL}$ [35]) (Fig. S1A), indicating that mitotic cells contain 1.4 times more phosphate groups on proteins than asynchronous cells. These results were consistent with an observed decrease in the ATP concentration as determined using a FRET probe (Fig. S1B, C, D) $(32,33)$, and this decrease was inhibited by the universal kinase inhibitor staurosporine (Fig. S2A, B). The reduction in the ATP concentration was not due to cell swelling during mitosis $(34,35)$ (Fig. S1E), rearrangement of the actin cytoskeleton (Fig. S2C, D), or a decrease in the ATP supply (glycolysis and oxidative phosphorylation) (Fig. S2E-H). These results indicate that although both phosphorylation and dephosphorylation occur during mitosis, phosphorylation is the dominant process. 


\section{Mitotic dephosphorylation occurs preferentially in non-structured regions}

144 The relationship between mitosis-specific phosphorylation/dephosphorylation and the higher-order structure of polypeptides was also investigated. A previous study reported that phosphorylation of substrate proteins tends to occur in non-structured regions (IDRs) (5). We therefore evaluated the intrinsic disorder score of individual residues using the IUPred method $(36,37)$. In this study, the minimum length of the IDR was set to 30 amino acid residues (see Materials and Methods). Using this criterion, 23.4\% of Ser/Thr residues among all cellular proteins are present in IDRs (Fig. 2A). In contrast, 59.6\% of the 10,255 phosphosites quantified in our proteomic analysis were assigned in IDRs (Fig. 2A), demonstrating the strong likelihood of phosphorylation occurring in IDRs. As a comparison, other post-translational modifications were also subjected to the same analysis. As shown in Figure S3, the probabilities of ubiquitylation, methylation and acetylation sites existing in IDRs were lower than that of phosphorylation, confirming that this likelihood is specific to phosphorylation and not general tendency of post-translational modifications.

We then examined the relationship between mitotic phosphorylation/dephosphorylation and IDRs.

As shown in Figure 2A, 71.0\% of DOWN and $52.6 \%$ of UP sites were found in IDRs. Interestingly, a strong inverse correlation between abundance ratio and IDR probability was found; the IDR probability gradually decreased from $\sim 80$ to $40 \%$ with increasing abundance ratio (Fig. $2 \mathrm{~B}$ ). These values were extremely high compared to the average for all Ser/Thr residues (23.4\%). Collectively, these results demonstrate that phosphorylation generally occurs preferentially in IDRs, and this is particularly and significantly true for dephosphorylation upon entry to mitosis.

The specific phosphosite amino acid residue was also strongly correlated with the mitotic abundance ratio. As shown in Figure $2 \mathrm{C},>90 \%$ of DOWN sites involved Ser, versus only $\sim 7.8 \%$ for Thr residues. The percentage of Ser residues decreased as the mitotic abundance increased; $75.2 \%$ of UP sites were Ser, and $24.8 \%$ were Thr, indicating that mitotic dephosphorylation occurs primarily at Ser residues, whereas mitotic 
phosphorylation occurs at both at Ser and Thr residues. These results could be explained at least in part by the strong correlation between IDRs and DOWN sites, as Ser has a higher disorder probability than Thr. Alternatively, this could be associated with phosphatase preference. PP2A is known to prefer Thr over Ser and be inactivated at mitosis entry and re-activated in anaphase, as demonstrated previously $(21,22,38,39)$ (see Discussion).

Mitotic phosphorylation-specific non-conventional sequence motifs

173 Next, we analyzed the sequence motifs specific to the UP and DOWN phosphosites. The UP and DOWN phosphosites were assigned as one of the following consensus sequences based on their flanking amino acids (from -6 to +6): "proline-directed" ([pS/pT]-P), phosphorylated by CDK and MAPK; "acidophilic" ([pS/pT]$\mathrm{X}-\mathrm{X}-[\mathrm{D} / \mathrm{E}],[\mathrm{pS} / \mathrm{pT}]-\mathrm{X}-[\mathrm{D} / \mathrm{E}]$ or $[\mathrm{D} / \mathrm{E}]-\mathrm{X}-[\mathrm{pS} / \mathrm{pT}])$, recognized by PLK1 and casein kinase; "basophilic" ([K/R]$\mathrm{X}-\mathrm{X}-[\mathrm{pS} / \mathrm{pT}]$ or $[\mathrm{K} / \mathrm{R}]-\mathrm{X}-[\mathrm{pS} / \mathrm{pT}])$, phosphorylated by Aurora kinase, PKC, and PKA $(2,40)$; and "nonconventional" for those that did not match any of the three above categories.

As shown in Figure 3A and B, three conventional motifs ("proline-directed", "acidophilic", and "basophilic") constituted $92.3 \%$ of DOWN sites, indicating that most mitotic dephosphorylation occurs at one of these conventional motifs. Interestingly, the amount of phosphorylation occurring at non-conventional motifs was higher for UP sites than DOWN sites (Figs. 3A and S4), suggesting the possibility of a mitosis-specific non-conventional motif. The conventional and non-conventional motifs also exhibited a clear contrast with regard to the relationship between the probability of phosphosites in IDR and mitotic abundance. As shown in Figure $3 \mathrm{C}$, the probability of an IDR was inversely correlated with the mitotic abundance ratio for all three conventional motifs, as demonstrated in Figure 2A. In a clear contrast, the IDR probability in non-conventional motifs increased with increasing abundance ratio (Fig. 3C). The high IDR probability of UP sites was opposite to that of the conventional motifs. These results suggest that non-conventional motifs in IDRs are 
phosphorylated upon entry to mitosis.

We then analyzed the amino acid sequences of "non-conventional" motifs. Logo analysis of 557 UP

phospho-serine and 79 UP phospho-threonine sites in non-conventional motifs revealed a high frequency of basic residues (Lys or Arg) on the carboxylic side (+2 to +6 ) of the phosphosite (Fig. 3D). The presence of K/R at the +3 position was particularly notable. In contrast, no clear consensus was found regarding the aminoterminal side of the phosphosites, except for a weak consensus of a hydrophobic residue at the -2 position and $\mathrm{K} / \mathrm{R}$ at the -6 position. This consensus was found to be distinct from any other known kinase motifs, including the conventional basophilic motif, which consists of a basic amino acid at the -2 or -3 position. In a clear contrast, no such consensus was found with respect to the DOWN sites; with no clear consensus for the 133 DOWN phospho-serine and 20 DOWN phospho-threonine sites in the non-conventional motifs (Fig. 3E). These results suggest that the non-conventional basophilic motifs (Non-conventional basic residues at $\underline{\text { carboxylic side }}$ motif (NBC motif)) are unique mitosis-specific phosphorylation sites.

GO term analyses were conducted for proteins carrying an UP site in the non-conventional motif (502 proteins). In contrast to the results of GO term analyses of all phosphoproteins with an UP site, proteins related to "mRNA export from the nucleus" were highly enriched in NBC motifs ( 24 of 502 proteins with nonconventional motifs [4.8\%] vs. 50 of all 1,955 proteins with UP sites [2.6\%]) (Fig. 3F). These proteins contain subunits of the nuclear pore complex (Nups), splicing factors, and other RNA-binding proteins. Nups and proteins with transcription regulator activity are known to carry a substantial number of IDRs $(41,42)$. These results, together with those regarding dephosphorylation of RNA-related proteins (Fig. 1D), suggest that phosphorylation/dephosphorylation of RNA-related proteins play important roles in the progression of mitosis.

\section{Discussion}

In this study, we conducted a comparative proteomic analysis of amino acid residues phosphorylated in cells 
undergoing mitosis and interphase cells using a TMT-6plex labeling technique that provides a ratio of the amounts of individual peptides in six samples with high precision (43). Using this approach, we extracted two different populations of phosphopeptides, one up-regulated and the other down-regulated upon entry to mitosis. Bioinformatic analyses of these phosphopeptides revealed a clear correlation between phosphorylation/dephosphorylation and the IDR probability of the substrate. The most striking outcome of our analysis was that although phosphorylation generally tends to occur in IDRs, this trend is more common with mitotic dephosphorylation, as $>70 \%$ of DOWN sites were found in IDRs, versus only $50 \%$ of UP sites (Fig. 2A, B). These data indicate that a significant number of phosphate groups are removed from IDRs and introduced into more structured regions upon entry to mitosis. Although we did not elucidate the significance of this translocation of phosphate groups from IDRs to structured regions in this study, several intriguing clues can be discerned from analyses of flanking amino acid sequences and GO term analysis: i) most mitotic dephosphorylation occurs at Ser residues (91.9\%), whereas phosphorylation occurs at both Ser and Thr residues (75.2\%, 24.8\%, respectively) (Fig. 2C); ii) proteins involved in mitotic chromosome segregation are heavily phosphorylated, whereas proteins related to RNA splicing and metabolism are both dephosphorylated and phosphorylated (Fig. 1D); and iii) non-conventional basic motifs are preferentially phosphorylated during mitosis (Fig. 3A, D, E). These intriguing results suggest a correlation between mitotic phosphorylation and dynamic higher-order assembly/disassembly of biomolecules (proteins, DNA, and RNA). Below, we discuss the potential significance of such dynamic behavior of biomolecules in the context of cellular function.

One effect of phosphorylation in IDRs could be to facilitate the transition of higher-order structures $(8,44,45)$. Phosphorylation in IDRs is known to cause disordered-to-ordered and ordered-to-disordered transitions. For example, phosphorylation of 4E-BP2 induces the formation of a four-stranded $\beta$-sheet, thus preventing the binding of eIF4E (46). Phosphorylation of phospholamban at Ser16, in contrast, disrupts the higher-order structure, in turn reducing the inhibitory effect of phospholamban on sarco(endo)plasmic Ca- 
ATPase activity $(47,48)$.

Another possible role for phosphorylation in IDRs is regulation of the phase transition of biomolecules. Non-structured polypeptides of IDRs have been demonstrated to play key roles in liquid-liquid phase separation (49). It is driven by a number of promiscuous interactions to assemble a number of molecules. Other studies demonstrated that phase transition of protein liquid droplets is induced by phosphorylation/dephosphorylation (50-52). For example, liquid-liquid phase separation of a complex of a positively charged artificial peptide and RNA is promoted by dephosphorylation of the peptide (53). A study using a short hydrophobic peptide that forms a hydrogel demonstrated that reversible gel-sol transition is induced by cyclic phosphorylation-dephosphorylation by kinases and phosphatases (54). The peptide hydrogel is transformed into solution upon addition of kinase and ATP to the gel and re-solidifies when phosphatase is added to the solution. Such phenomena have also been observed in living cells. The assembly/disassembly of RNA granules is regulated by phosphorylation/dephosphorylation of one of the subunits (55). Although the mechanism is not fully understood, available evidence suggests a possible effect of phosphorylation/dephosphorylation on the dynamic assembly/disassembly transition of biomolecules upon entry to mitosis. It is possible that phosphate groups in IDRs function in weakly assembling the proteins during interphase, and their removal (dephosphorylation) could induce final assembly of the proteins into a stable complex. Alternatively, mitotic phosphorylation could solubilize/disassemble the protein complex, and dephosphorylation during anaphase could reassemble the complex. Indeed, phosphorylation of proteins in splicing speckles, pericentriolar-satellites, and stress granule by DYRK3 results in disassembly of these membrane-less organelles during mitosis (56). Such phosphorylation-dependent regulation of protein assembly/disassembly depends on the sequence of amino acid residues flanking the substrate residue. A previous report demonstrated that the charge pattern — rather than the net charge —is most important for phase separation (57). The addition of a negative charge due to phosphorylation could enhance or disrupt the charge 
pattern and thus affect the progress of phase separation.

Our GO term analysis of UP and DOWN phosphosites revealed that RNA-related proteins are preferentially dephosphorylated and phosphorylated during mitosis (Fig. 1D). This result is intriguing in the context of phosphorylation-dependent regulation of phase transition in intracellular compartments. A recent study demonstrated that the structure and function of several intracellular compartments are maintained by phase separation, in which RNA plays a role in the molecular assembly (58). P-granules are cytoplasmic compartments in the germ line of $C$. elegans, and they are considered liquid-like condensates containing mRNA and RNA-binding proteins that function in posttranscriptional regulation $(59,60)$. Protein components of $\mathrm{P}$ granules, such as PGL-3 and LAF-1, form liquid droplets in vitro, and mRNA affects the dynamics of these proteins within the droplets $(64,65)$. In the nucleolus, which is also considered a compartment, proteins and RNAs assemble via a mechanism similar to phase separation (63). The nucleolar protein nucleophosmin forms droplets with rRNA in vitro (64). Phosphorylation of Thr ${ }^{199,219,234,237}$ by CDK1 reduces the affinity for rRNA (65), and replacement of these Ser residues with Glu partially abolishes nucleolar localization in HeLa cells (66), suggesting that phosphorylation of nucleophosmin controls the dynamics of proteins and RNAs within the nucleolus. It is possible that the removal/addition of a large number of phosphate groups from/to IDRs of RNArelated proteins induces dynamic rearrangements of the nucleolus and other RNA-containing nuclear speckles upon entry to mitosis, resulting in disruption of these organelles and the release of a large number of RNA molecules into the cytoplasm. This would dramatically alter the intracellular environment and could affect the assembly/disassembly dynamics of other protein complexes, such as chromosomes, which are known to contain pre-ribosomal RNA and nucleolar proteins on the surface $(67,68)$. It is also possible that chromosome condensation could be induced by the orchestrated effects of phosphorylation of chromosome-related proteins (Fig. 1D) and dramatic RNA-induced changes in the intracellular environment. Further study will be required to resolve this issue. 

was found to occur at Ser residues, whereas phosphorylation was found to occur at both Ser and Thr residues (Fig. 2C), suggesting that Thr phosphorylation is a mitosis-specific event. It is possible that such Thr phosphorylation of substrate proteins is coupled with dephosphorylation during anaphase and therefore temporary during early mitosis. There are several lines of experimental evidence that support this possibility: i) dephosphorylation during anaphase and telophase occur preferentially at Thr residues in HeLa cells $(22,38)$; ii) in budding yeast, Thr residues are heavily phosphorylated upon entry to mitosis and dephosphorylated during anaphase by PP2 $\mathrm{A}^{\mathrm{Cdc55}}$, an orthologue of $\mathrm{PP}_{2} \mathrm{~A}^{\mathrm{B} 55}(21,39,69)$; iii) biochemical analyses revealed that PP2A $\mathrm{A}^{\mathrm{B} 55}$, a major anaphase-associated phosphatase, preferentially dephosphorylates Thr residues over Ser residues (70); and iv) a comparison of our dataset of UP sites with a previously reported dephosphorylation dataset (22) revealed that $29.9 \%$ of Thr and $9.4 \%$ of Ser residues detected in the both datasets are dephosphorylated during anaphase. These data suggest that Thr phosphorylation during mitosis is temporary and functions to regulate reactions that are tightly tuned temporally during mitosis. The combined activities of kinases and phosphatases enable such tight regulation. Although the structural background of Thr-specific reactions has yet to be elucidated, it must be involved in early mitotic events such as chromosome condensation. subtypes contain basic residues on the C-terminal side as well (40). PKC $\varepsilon$ plays a role in resolving mitotic DNA catenation (73). Our GO term analysis revealed that proteins related to sister chromatid segregation are enriched in proteins carrying NBC motifs. Another potential candidate is AMPK, which is activated when AMP levels 
primary consensus motif for AMPK is basophilic, a peptide with $\mathrm{K} / \mathrm{R}$ at the +3 position, which is the same as the NBC motif, is also phosphorylated in vitro (76). Of 243 proteins identified as substrates of AMPK to date (75), 17.3\% (42 proteins) were found to contain UP sites in the NBC motif in our study (Table S2). Furthermore, that mitosis is regulated by an ATP-dependent regulatory mechanism; decreasing intracellular ATP levels resulting from the activity of conventional kinases upon entry to mitosis may activate AMPK, which then phosphorylates different sets of substrate proteins to induce the progression of mitosis. The activity of AMPK increases during early mitosis and then decreases when cytokinesis begins (75), in good agreement with observed ATP levels during mitosis (Fig. S1C).

\section{Materials and Methods}

\section{Cell culture and synchronization}

HeLa cells were cultured in Dulbecco's modified eagle medium (DMEM) (Sigma-Aldrich) with 10\% fetal bovine serum (FBS) (GIBCO) at $37^{\circ} \mathrm{C}$ and $5 \% \mathrm{CO}_{2}$. For mitosis-arrested cells, cells were treated first with 2 mM thymidine (Sigma-Aldrich) for $18 \mathrm{~h}$, washed with PBS, and released into DMEM with $10 \%$ FBS for $1 \mathrm{~h}$. Following treatment with $0.2 \mu \mathrm{M}$ nocodazole for $10 \mathrm{~h}, 80 \%$ synchronization of HeLa cells in mitosis was achieved.

\section{TMT labeling and mass spectrometry}

323 Asynchronous and mitosis-arrested HeLa cells in 100-mm cell culture dishes (Corning) were washed twice with hydrochloride buffer (6 M guanidine hydrochloride, $100 \mathrm{mM}$ Tris-HCl [pH 8.0], 2 mM DTT) was added, and cell lysates were prepared in triplicate and frozen in liquid nitrogen. The lysates were dissolved by heating and 
sonication, followed by centrifugation at $20,000 \times g$ for $15 \mathrm{~min}$ at $4^{\circ} \mathrm{C}$. The supernatants were reduced in $5 \mathrm{mM}$

DTT at room temperature for $30 \mathrm{~min}$ and alkylated in $27.5 \mathrm{mM}$ iodoacetamide at room temperature for $30 \mathrm{~min}$

in the dark. Proteins were purified by methanol/chloroform precipitation and solubilized by addition of $25 \mu \mathrm{L}$

of $0.1 \%$ RapiGest SF (Waters) in $50 \mathrm{mM}$ triethylammonium bicarbonate. After repeated sonication and

vortexing, the proteins were digested with $2 \mu \mathrm{g}$ of trypsin/Lys-C mix (Promega) for $16 \mathrm{~h}$ at $37^{\circ} \mathrm{C}$. The peptide concentration was determined using a Pierce quantitative colorimetric peptide assay (Thermo Fisher Scientific).

Approximately $150 \mu \mathrm{g}$ of peptides for each sample was labeled with $200 \mu \mathrm{g}$ of TMT-6plex reagent (Thermo

Fisher Scientific) for $1 \mathrm{~h}$ at room temperature. After the reaction was quenched with hydroxylamine, all TMTlabeled samples were pooled and acidified with trifluoroacetic acid (TFA). Phosphopeptides were enriched using a 50-mg column of Titansphere Phos-TiO (GL Sciences) in accordance with the manufacturer's instructions and then fractionated using a Pierce high-pH reversed-phase peptide fractionation kit (Thermo

Fisher Scientific). Eight fractions were collected: 5, 7.5, 10, 12.5, 15, 17.5, 20, and 50\% acetonitrile. Each fraction was evaporated in a SpeedVac concentrator and dissolved in $0.1 \%$ TFA.

Data analysis was used. The term "BP_5" was obtained as a biological process term applying Homo sapiens as the background. The number of proteins in our dataset was divided by the total number of proteins for each GO term to evaluate the abundance of the term. For IDR analysis, the IUPred method $(36,37)$ was used. Position-specific estimations of energies of each residue were calculated based on the method described by Dosztányi using Perl script. 
350 to the IUPred method. Contiguous amino acid sequences of more than 30 intrinsically disordered residues were 351 regarded as intrinsically disordered regions. LOGO analysis of the neighboring amino acids of phosphosites 352 was performed using the "PSP production" algorithm in PhosphoSitePlus (25).

\section{Acknowledgments}

355 This study was supported financially by The Sumitomo Foundation Grant for Basic Science Research Projects 356 (Grant Number 150852) for S.H.Y and JSPS Grant-in-Aid for JSPS Fellows (Grant Number 17J09002) for H.Y. 357 We thank T. Oda for the assistance in the analysis of IDR. 

phosphoproteomics reveals widespread full phosphorylation site occupancy during mitosis. Sci Signal.

3, ra3 (2010).

2. N. Dephoure, C. Zhou, J. Villen, S.A. Beausoleil, C.E. Bakalarski, S.J. Elledge, et al., A quantitative

4. M.M. Roux, M.J. Radeke, M. Goel, A. Mushegian, K.R. Foltz, 2DE identification of proteins exhibiting turnover and phosphorylation dynamics during sea urchin egg activation. Dev Biol. 313, 630-647 (2008).

5. $\quad$ L.M. Iakoucheva, P. Radivojac, C.J. Brown, T.R. O'Connor, J.G. Sikes, Z. Obradovic, et al., The importance of intrinsic disorder for protein phosphorylation. Nucleic Acids Res. 32, 1037-1049 (2004).

6. A.L. Darling, V.N. Uversky, Intrinsic disorder and posttranslational modifications: The darker side of the biological dark matter. Front Genet. 9, 1-18 (2018).

7. M.O. Collins, L. Yu, I. Campuzano, S.G.N. Grant, J.S. Choudhary, Phosphoproteomic Analysis of the Mouse Brain Cytosol Reveals a Predominance of Protein Phosphorylation in Regions of Intrinsic Sequence Disorder. Mol Cell Proteomics. 7, 1331-1348 (2008).

8. K. Kasahara, M. Shiina, J. Higo, K. Ogata, H. Nakamura, Phosphorylation of an intrinsically disordered region of Ets1 shifts a multi-modal interaction ensemble to an auto-inhibitory state. Nucleic Acids Res. 46, 2243-2251 (2018).

9. W.D. Nelson, S.E. Blakely, Y.E. Nesmelov, D.D. Thomas, Site-directed spin labeling reveals a conformational switch in the phosphorylation domain of smooth muscle myosin. Proc Natl Acad Sci. 102, 4000-4005 (2005). 
bioRxiv preprint doi: https://doi.org/10.1101/636407; this version posted June 22,2019 . The copyright holder for this preprint (which was not certified by peer review) is the author/funder, who has granted bioRxiv a license to display the preprint in perpetuity. It is made available under aCC-BY-NC-ND 4.0 International license.

10. L.M. Espinoza-Fonseca, D. Kast, D.D. Thomas, Molecular dynamics simulations reveal a disorder-toorder transition on phosphorylation of smooth muscle myosin. Biophys J. 93, 2083-2090 (2007).

11. L.M. Espinoza-Fonseca, D. Kast, D.D. Thomas, Thermodynamic and structural basis of phosphorylation-induced disorder-to-order transition in the regulatory light chain of smooth muscle myosin. J Am Chem Soc. 130, 12208-12209 (2008).

12. F. Ardito, M. Giuliani, D. Perrone, G. Troiano, L. Lo Muzio, The crucial role of protein phosphorylation in cell signalingand its use as targeted therapy (Review). Int J Mol Med. 40, 271-280 (2017).

13. H. Horn, E.M. Schoof, J. Kim, X. Robin, M.L. Miller, F. Diella, et al., KinomeXplorer: An integrated platform for kinome biology studies. Nat Methods. 11, 603-604 (2014).

14. H.L. Rust, P.R. Thompson, Kinase consensus sequences: A breeding ground for crosstalk. ACS Chem Biol. 6, 881-892 (2011).

15. F. Bazile, J. St-Pierre, D. D’Amours, Three-step model for condensin activation during mitotic chromosome condensation. Cell Cycle. 9, 3243-3255 (2010).

16. G. Wang, Q. Jiang, C. Zhang, The role of mitotic kinases in coupling the centrosome cycle with the assembly of the mitotic spindle. J Cell Sci. 127, 4111-4122 (2014).

17. R. Bayliss, A. Fry, T. Haq, S. Yeoh, On the molecular mechanisms of mitotic kinase activation. Open Biol. 2, 120136-120136 (2012).

18. E.A. Nigg, Mitotic kinases as regulators of cell division and its checkpoints. Nat Rev Mol Cell Biol. 2 , 21-32 (2001).

19. M. Alvarez-Fernandez, M. Malumbres, Preparing a cell for nuclear envelope breakdown: Spatiotemporal control of phosphorylation during mitotic entry. BioEssays. 36, 757-765 (2014).

20. F.A. Barr, P.R. Elliott, U. Gruneberg, Protein phosphatases and the regulation of mitosis. J Cell Sci. 
124, 2323-2334 (2011).

21. H. Kim, G. Fernandes, C. Lee, Protein Phosphatases Involved in Regulating Mitosis: Facts and Hypotheses. Mol Cells. 39, 654-62 (2016).

22. A. Castro, R.A. McCloy, S. Rogers, N.J. Hoffman, B.L. Parker, T. Lorca, et al., Global Phosphoproteomic Mapping of Early Mitotic Exit in Human Cells Identifies Novel Substrate Dephosphorylation Motifs. Mol Cell Proteomics. 14, 2194-2212 (2015).

23. E. Perdiguero, A.R. Nebreda, Regulation of Cdc25C activity during the meiotic G2/M transition. Cell Cycle. 3, 733-737 (2004).

24. O. Timofeev, O. Cizmecioglu, F. Settele, T. Kempf, I. Hoffmann, Cdc25 phosphatases are required for timely assembly of CDK1-cyclin B at the G2/M transition. J Biol Chem. 285, 16978-16990 (2010).

25. P. V. Hornbeck, B. Zhang, B. Murray, J.M. Kornhauser, V. Latham, E. Skrzypek, PhosphoSitePlus, 2014: Mutations, PTMs and recalibrations. Nucleic Acids Res. 43, D512-D520 (2015).

26. R. Rizkallah, K.E. Alexander, M.M. Hurt, Global mitotic phosphorylation of C2H2 zinc finger protein linker peptides. Cell Cycle. 10, 3327-3336 (2011).

27. C. Crosio, G.M. Fimia, R. Loury, Y. Okano, H. Zhou, S. Sen, et al., Mitotic Phosphorylation of Histone H3 : Spatio-Temporal Regulation by Mammalian Aurora Kinases. 22, 874-885 (2002).

28. D.W. Huang, B.T. Sherman, R.A. Lempicki, Systematic and integrative analysis of large gene lists using DAVID bioinformatics resources. Nat Protoc. 4, 44-57 (2009).

29. D.W. Huang, B.T. Sherman, R.A. Lempicki, Bioinformatics enrichment tools: Paths toward the comprehensive functional analysis of large gene lists. Nucleic Acids Res. 37, 1-13 (2009).

30. L. Pan, L. Wang, C.-C. Hsu, J. Zhang, A. Iliuk, W.A. Tao, Sensitive measurement of total protein phosphorylation level in complex protein samples. Analyst. 140, 3390-3396 (2015).

31. A. Fujioka, K. Terai, R.E. Itoh, K. Aoki, T. Nakamura, S. Kuroda, et al., Dynamics of the Ras/ERK 
bioRxiv preprint doi: https://doi.org/10.1101/636407; this version posted June 22,2019 . The copyright holder for this preprint (which was

not certified by peer review) is the author/funder, who has granted bioRxiv a license to display the preprint in perpetuity. It is made available under aCC-BY-NC-ND 4.0 International license.

MAPK cascade as monitored by fluorescent probes. J Biol Chem. 281, 8917-8926 (2006).

32. E. Ahn, P. Kumar, D. Mukha, A. Tzur, T. Shlomi, Temporal fluxomics reveals oscillations in TCA cycle flux throughout the mammalian cell cycle. Mol Syst Biol. 13, 953 (2017).

33. K. Maeshima, T. Matsuda, Y. Shindo, H. Imamura, S. Tamura, R. Imai, et al., A Transient Rise in Free Mg 2+ Ions Released from ATP-Mg Hydrolysis Contributes to Mitotic Chromosome Condensation. Curr Biol. 1-8 (2018).

34. S. Son, J.H. Kang, S. Oh, M.W. Kirschner, T.J. Mitchison, S. Manalis, Resonant microchannel volume and mass measurements show that suspended cells swell during mitosis. J Cell Biol. 211, 757-763 (2015).

35. E. Zlotek-Zlotkiewicz, S. Monnier, G. Cappello, M. Le Berre, M. Piel, Optical volume and mass measurements show that mammalian cells swell during mitosis. J Cell Biol. 211, 765-774 (2015).

36. Z. Dosztányi, V. Csizmók, P. Tompa, I. Simon, The pairwise energy content estimated from amino acid composition discriminates between folded and intrinsically unstructured proteins. J Mol Biol. 347, $827-839$ (2005).

37. Z. Dosztányi, V. Csizmok, P. Tompa, I. Simon, IUPred: Web server for the prediction of intrinsically unstructured regions of proteins based on estimated energy content. Bioinformatics. 21, 3433-3434 (2005).

38. R. Malik, R. Lenobel, A. Santamaria, A. Ries, E.A. Nigg, R. Körner, Quantitative analysis of the human spindle phosphoproteome at distinct mitotic stages. J Proteome Res. 8, 4553-4563 (2009).

39. M. Godfrey, S.A. Touati, M. Kataria, A. Jones, A.P. Snijders, F. Uhlmann, PP2ACdc55 Phosphatase Imposes Ordered Cell-Cycle Phosphorylation by Opposing Threonine Phosphorylation. Mol Cell. 65, 393-402.e3 (2017).

40. A. Kreegipuu, N. Blom, S. Brunak, J. Ja, Statistical analysis of protein kinase specifcity determinants. 
bioRxiv preprint doi: https://doi.org/10.1101/636407; this version posted June 22,2019 . The copyright holder for this preprint (which was

not certified by peer review) is the author/funder, who has granted bioRxiv a license to display the preprint in perpetuity. It is made available under aCC-BY-NC-ND 4.0 International license.

FEBS Lett. 430, 45-50 (1998).

41. S.S. Patel, D.P. Denning, A.L. Fink, V. Uversky, M. Rexach, Disorder in the nuclear pore complex: The FG repeat regions of nucleoporins are natively unfolded. Proc Natl Acad Sci. 100, 2450-2455 (2003).

42. C. Haynes, C.J. Oldfield, F. Ji, N. Klitgord, M.E. Cusick, P. Radivojac, et al., Intrinsic disorder is a common feature of hub proteins from four eukaryotic interactomes. PLoS Comput Biol. 2, 0890-0901 (2006).

43. A. Hogrebe, L. Von Stechow, D.B. Bekker-Jensen, B.T. Weinert, C.D. Kelstrup, J. V. Olsen, Benchmarking common quantification strategies for large-scale phosphoproteomics. Nat Commun. 9, (2018). doi:10.1038/s41467-018-03309-6.

44. T. Travers, H. Shao, B.A. Joughin, D.A. Lauffenburger, A. Wells, C.J. Camacho, Tandem phosphorylation within an intrinsically disordered region regulates ACTN4 function. Sci Signal. 8, 110 (2015).

45. M.E. Fealey, B.P. Binder, V.N. Uversky, A. Hinderliter, D.D. Thomas, Structural Impact of Phosphorylation and Dielectric Constant Variation on Synaptotagmin's IDR. Biophys J. 114, 550-561 (2018).

46. A. Bah, R.M. Vernon, Z. Siddiqui, M. Krzeminski, R. Muhandiram, C. Zhao, et al., Folding of an intrinsically disordered protein by phosphorylation as a regulatory switch. Nature. 519, 106-9 (2015).

47. E.E. Metcalfe, N.J. Traaseth, G. Veglia, Serine 16 phosphorylation induces an order-to-disorder transition in monomeric phospholamban. Biochemistry. 44, 4386-4396 (2005).

48. G. Chu, E.G. Kranias, Functional interplay between dual site phospholambam phosphorylation: insights from genetically altered mouse models. Basic Res Cardiol. 97, 1-1 (2003).

49. V.N. Uversky, Intrinsically disordered proteins in overcrowded milieu: Membrane-less organelles, 
bioRxiv preprint doi: https://doi.org/10.1101/636407; this version posted June 22,2019 . The copyright holder for this preprint (which was not certified by peer review) is the author/funder, who has granted bioRxiv a license to display the preprint in perpetuity. It is made available under aCC-BY-NC-ND 4.0 International license.

phase separation, and intrinsic disorder. Curr Opin Struct Biol. 44, 18-30 (2017).

50. I. Kwon, M. Kato, S. Xiang, L. Wu, P. Theodoropoulos, H. Mirzaei, et al., Phosphorylation-regulated binding of RNA polymerase ii to fibrous polymers of low-complexity domains. Cell. 156, 374 (2014).

51. J. Guillén-Boixet, V. Buzon, X. Salvatella, R. Méndez, CPEB4 is regulated during cell cycle by ERK2/Cdk1-mediated phosphorylation and its assembly into liquid-like droplets. Elife. 5, 1-26 (2016).

52. Z. Monahan, V.H. Ryan, A.M. Janke, K.A. Burke, S.N. Rhoads, G.H. Zerze, et al., Phosphorylation of the FUS low-complexity domain disrupts phase separation, aggregation, and toxicity. EMBO J. 36, e201696394 (2017).

53. W.M. Aumiller, C.D. Keating, Phosphorylation-mediated RNA/peptide complex coacervation as a model for intracellular liquid organelles. Nat Chem. 8, 129-137 (2016).

54. Z. Yang, G. Liang, L. Wang, B. Xu, Using a kinase/phosphatase switch to regulate a supramolecular hydrogel and forming the supramolecular hydrogel in vivo. J Am Chem Soc. 128, 3038-3043 (2006).

55. J.T. Wang, J. Smith, B.C. Chen, H. Schmidt, D. Rasoloson, A. Paix, et al., Regulation of RNA granule dynamics by phosphorylation of serine-rich, intrinsically disordered proteins in C. elegans. Elife. 3, 1$23(2014)$.

56. A.K. Rai, J.X. Chen, M. Selbach, L. Pelkmans, Kinase-controlled phase transition of membraneless organelles in mitosis. Nature. 559, 211-216 (2018).

57. T.J. Nott, E. Petsalaki, P. Farber, D. Jervis, E. Fussner, A. Plochowietz, et al., Phase Transition of a Disordered Nuage Protein Generates Environmentally Responsive Membraneless Organelles. Mol Cell. 57, 936-947 (2015).

58. Y. Lin, D.S.W. Protter, M.K. Rosen, R. Parker, Formation and Maturation of Phase-Separated Liquid Droplets by RNA-Binding Proteins. Mol Cell. 60, 208-219 (2015).

59. D. Updike, S. Strome, P granule assembly and function in Caenorhabditis elegans germ cells. $J$ Androl. 
bioRxiv preprint doi: https://doi.org/10.1101/636407; this version posted June 22,2019 . The copyright holder for this preprint (which was not certified by peer review) is the author/funder, who has granted bioRxiv a license to display the preprint in perpetuity. It is made available under aCC-BY-NC-ND 4.0 International license.

31, 53-60 (2010).

60. G. Seydoux, The P Granules of C. elegans: A Genetic Model for the Study of RNA-Protein Condensates. J Mol Biol. 430, 4702-4710 (2018).

61. S. Saha, C.A. Weber, M. Nousch, O. Adame-Arana, C. Hoege, M.Y. Hein, et al., Polar Positioning of Phase-Separated Liquid Compartments in Cells Regulated by an mRNA Competition Mechanism.

Cell. 166, 1572-1584.e16 (2016).

62. S. Elbaum-Garfinkle, Y. Kim, K. Szczepaniak, C.C.-H. Chen, C.R. Eckmann, S. Myong, et al., The disordered P granule protein LAF-1 drives phase separation into droplets with tunable viscosity and dynamics. Proc Natl Acad Sci. 112, 7189-7194 (2015).

63. M. Feric, N. Vaidya, T.S. Harmon, D.M. Mitrea, L. Zhu, T.M. Richardson, et al., Coexisting Liquid Phases Underlie Nucleolar Subcompartments. Cell. 165, 1686-1697 (2016).

64. D.M. Mitrea, J.A. Cika, C.B. Stanley, A. Nourse, P.L. Onuchic, P.R. Banerjee, et al., Self-interaction of NPM1 modulates multiple mechanisms of liquid-liquid phase separation. Nat Commun. 9, 1-13 (2018).

65. M. Okuwaki, M. Tsujimoto, K. Nagata, The RNA Binding Activity of a Ribosome Biogenesis Factor, Nucleophosmin/B23, Is Modulated by Phosphorylation with a Cell Cycle-dependent Kinase and by Association with Its Subtype. Mol Biol Cell. 13, 2016-2030 (2002).

66. S.S. Negi, M.O.J. Olson, Effects of interphase and mitotic phosphorylation on the mobility and location of nucleolar protein B23. J Cell Sci. 119, 3676-3685 (2006).

67. A.A. Van Hooser, P. Yuh, R. Heald, The perichromosomal layer. Chromosoma. 114, 377-388 (2005).

68. Y. Hayashi, K. Kato, K. Kimura, The hierarchical structure of the perichromosomal layer comprises Ki67, ribosomal RNAs, and nucleolar proteins. Biochem Biophys Res Commun. 493, 1043-1049 (2017). 
bioRxiv preprint doi: https://doi.org/10.1101/636407; this version posted June 22,2019 . The copyright holder for this preprint (which was

not certified by peer review) is the author/funder, who has granted bioRxiv a license to display the preprint in perpetuity. It is made available under aCC-BY-NC-ND 4.0 International license.

69. C. Wurzenberger, D.W. Gerlich, Phosphatases: Providing safe passage through mitotic exit. Nat Rev Mol Cell Biol. 12, 469-482 (2011).

70. L.A. Pinna, A. Donella-Deana, Phosphorylated synthetic peptides as tools for studying protein phosphatases. BBA - Mol Cell Res. 1222, 415-431 (1994).

71. Z. Dai, N.G. Dulyaninova, S. Kumar, A.R. Bresnick, D.S. Lawrence, Visual Snapshots of Intracellular Kinase Activity at the Onset of Mitosis. Chem Biol. 14, 1254-1260 (2007).

72. S. Martini, T. Soliman, G. Gobbi, P. Mirandola, C. Carubbi, E. Masselli, et al., PKCe Controls Mitotic Progression by Regulating Centrosome Migration and Mitotic Spindle Assembly. Mol Cancer Res. 3$16(2017)$.

73. N. Brownlow, T. Pike, D. Zicha, L. Collinson, P.J. Parker, Mitotic catenation is monitored and resolved by a PKC-regulated pathway. Nat Commun. 5, 1-13 (2014).

74. D.G. Hardie, AMP-activated/SNF1 protein kinases: Conserved guardians of cellular energy. Nat Rev Mol Cell Biol. 8, 774-785 (2007).

75. M.R. Banko, J.J. Allen, B.E. Schaffer, E.W. Wilker, P.P. Tsou, J.L. White, et al., Chemical Genetic Screen for AMPKa2 Substrates Uncovers a Network of Proteins Involved in Mitosis. Mol Cell. 44, 878-892 (2011).

76. D.M. Gwinn, D.B. Shackelford, D.F. Egan, M.M. Mihaylova, A. Mery, D.S. Vasquez, et al., AMPK Phosphorylation of Raptor Mediates a Metabolic Checkpoint. Mol Cell. 30, 214-226 (2008). 
bioRxiv preprint doi: https://doi.org/10.1101/636407; this version posted June 22, 2019. The copyright holder for this preprint (which was

not certified by peer review) is the author/funder, who has granted bioRxiv a license to display the preprint in perpetuity. It is made available under aCC-BY-NC-ND 4.0 International license.

A $\quad$ abundance in mitosis UP $(p<0.01)$
DOWN $(p<0.01)$

- $p \geq 0.01$

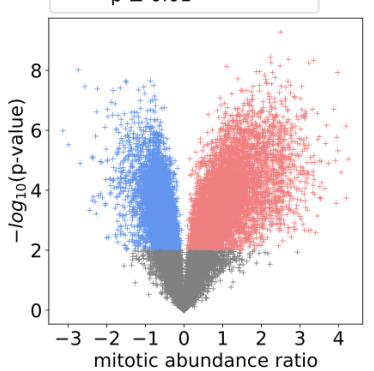

B

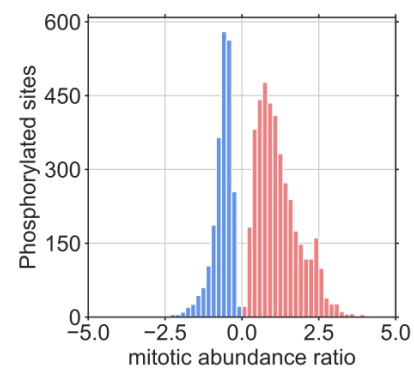

C

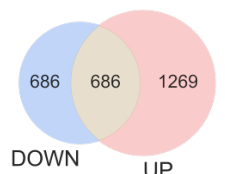

D

D sister chromatid segregation

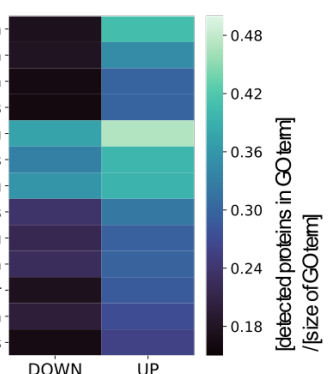

DOWN

UP

Yamazaki et al. Figure 1 
bioRxiv preprint doi: https://doi.org/10.1101/636407; this version posted June 22, 2019. The copyright holder for this preprint (which was

not certified by peer review) is the author/funder, who has granted bioRxiv a license to display the preprint in perpetuity. It is made available under aCC-BY-NC-ND 4.0 International license.
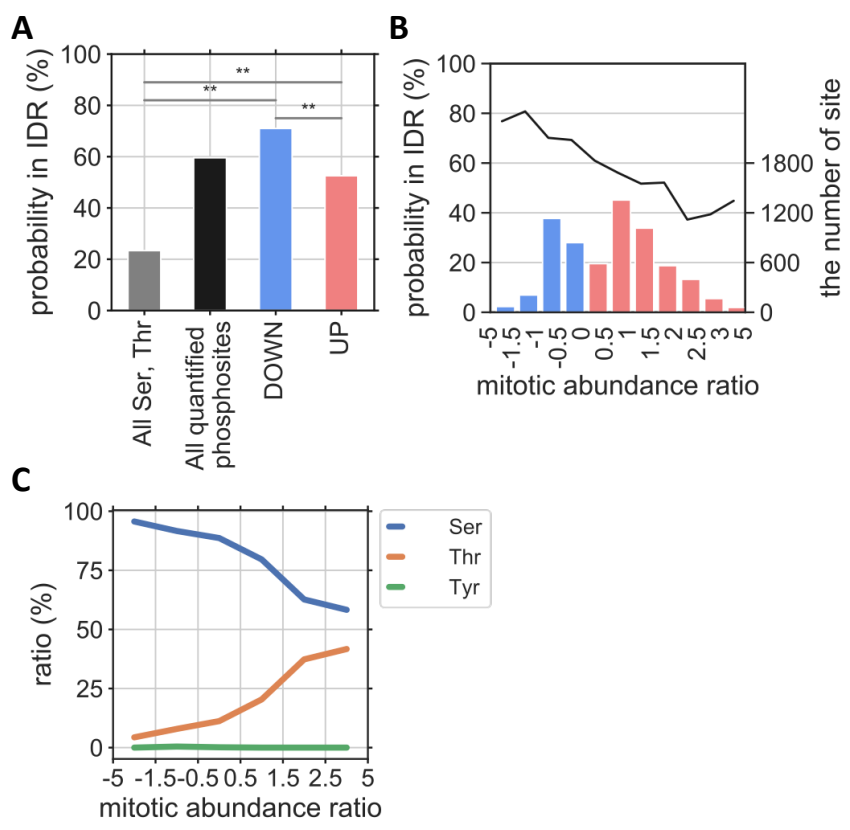

Yamazaki et al. Figure 2 
bioRxiv preprint doi: https://doi.org/10.1101/636407; this version posted June 22, 2019. The copyright holder for this preprint (which was

not certified by peer review) is the author/funder, who has granted bioRxiv a license to display the preprint in perpetuity. It is made available under aCC-BY-NC-ND 4.0 International license.

A

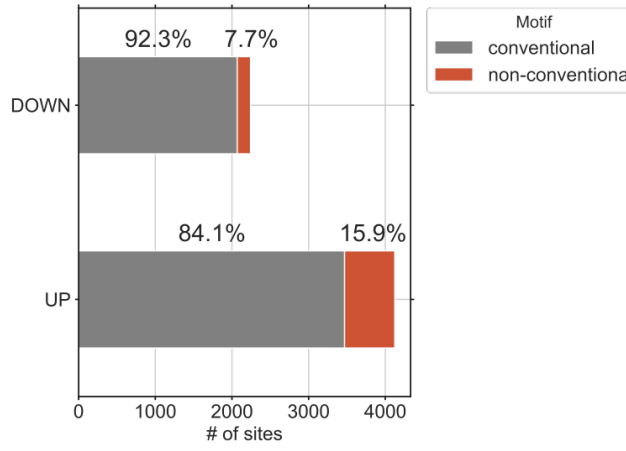

B
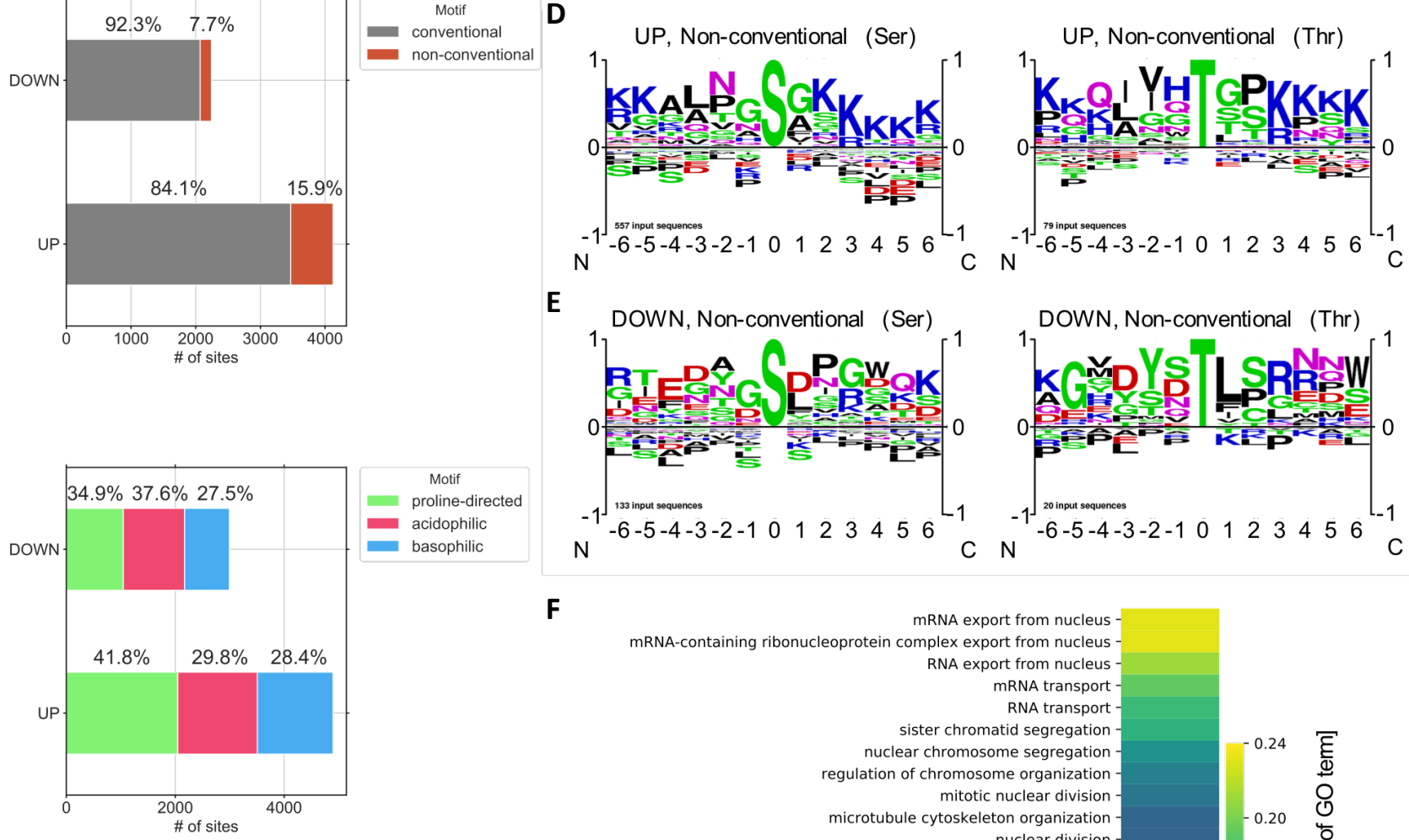

E

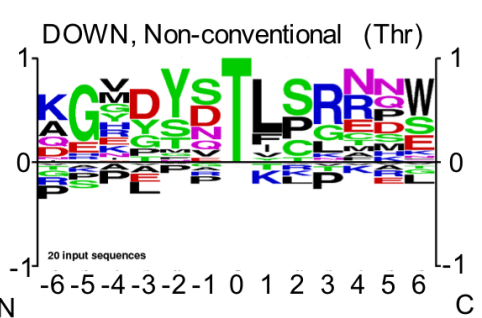

$\mathbf{F}$

C

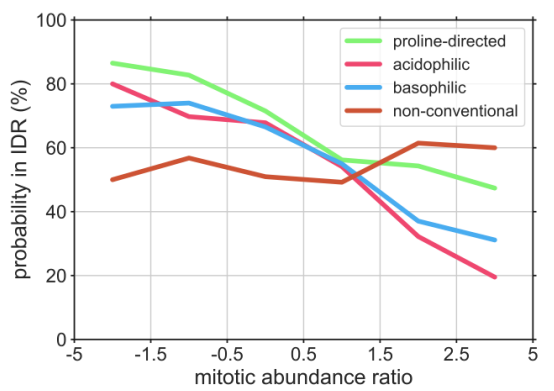

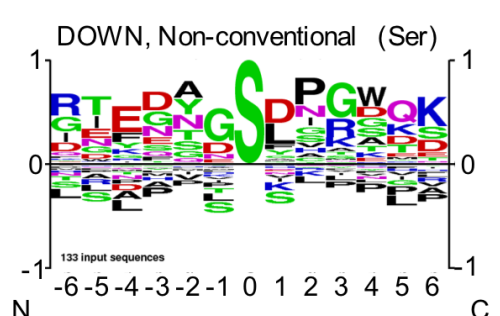

N

$\mathrm{N}$

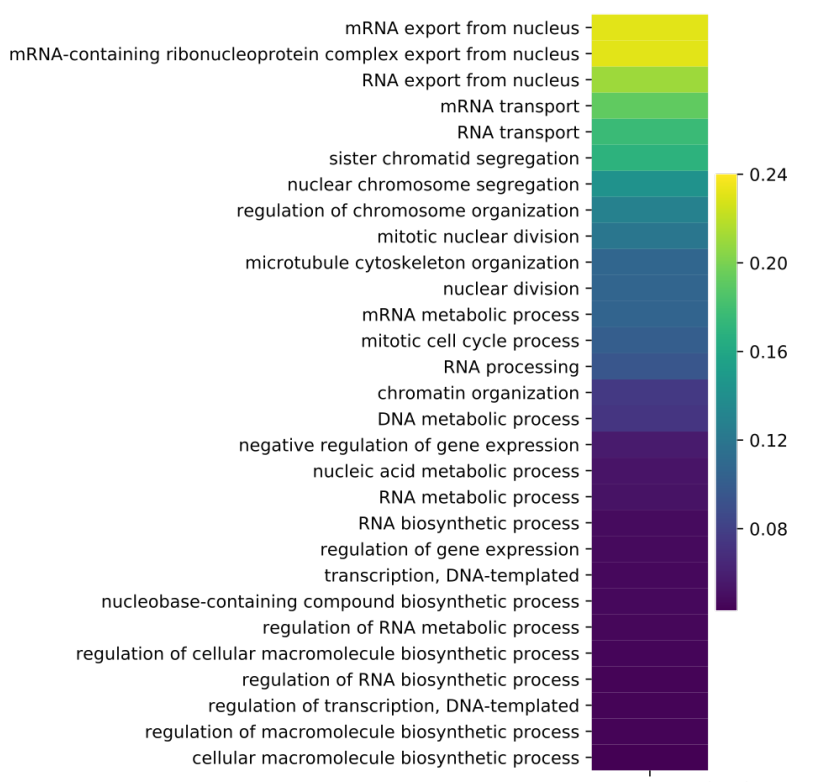




\section{$544 \quad$ Figure Legends}

Figure 1.

Quantification of mitotic phosphorylation by tandem mass tag analysis and gene ontology analysis on detected proteins. (A) Volcano plot of the TMT-analysis. The p-values and abundance ratios of individual phosphopeptides were plotted. Peptides with a $-\log _{10}$ (p-value) $<2$ (grey) were eliminated from the subsequent analyses. Positive (red) and negative (blue) peptides were extracted and subjected to subsequent analyses. (B) Histogram of the abundance ratio. UP (red) and DOWN (blue) sites are distinguished. (C) Venn diagram of the number of proteins containing UP and/or DOWN sites. (D) Gene ontology analysis of phosphoproteins containing UP or DOWN sites. Biological process terms were obtained using DAVID. The number of proteins identified in this study was divided by the total number of proteins associated with each term. Shown are several terms relatively abundant for peptides with UP and DOWN sites.

Figure 2.

Structural properties and modified residues of mitotic phosphosites. (A) Probability of phosphosites existing in intrinsically disordered regions. The IDR probabilities of all Ser and Thr residues, phosphosites, UP sites, and DOWN sites are plotted. ${ }^{* *} P<0.01$. (B) Relationship between IDR probability and abundance ratio. (C) Relationship between phosphosite amino acid residue and abundance ratio.

\section{Figure 3.}

Neighboring sequences of mitotic phosphosites and the detected mitotic unconventional phosphorylation

motif. (A, B) Ratio of conventional and non-conventional motifs (A) and ratio of individual conventional motifs (B) in UP and DOWN sites. (C) Relationship between IDR probability and abundance ratio for 
bioRxiv preprint doi: https://doi.org/10.1101/636407; this version posted June 22, 2019. The copyright holder for this preprint (which was

not certified by peer review) is the author/funder, who has granted bioRxiv a license to display the preprint in perpetuity. It is made available under aCC-BY-NC-ND 4.0 International license.

567 individual conventional and non-conventional motifs. (D, E) Logo analysis of residues flanking UP (D) and

568 DOWN (E) sites in non-conventional motifs. Results for phospho-serine (left) and phospho-threonine (right)

569 are shown. (F) Gene ontology (biological process) analysis of proteins with UP sites in non-conventional

570 motifs. The number of proteins identified was divided by the total number of proteins associated with each

571 term. 
A

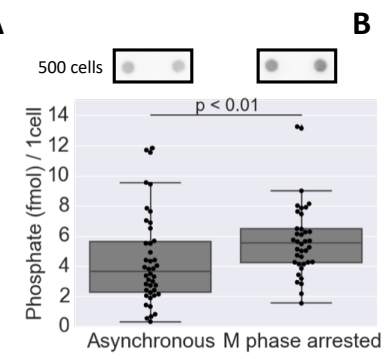

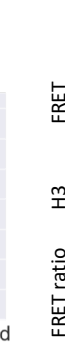
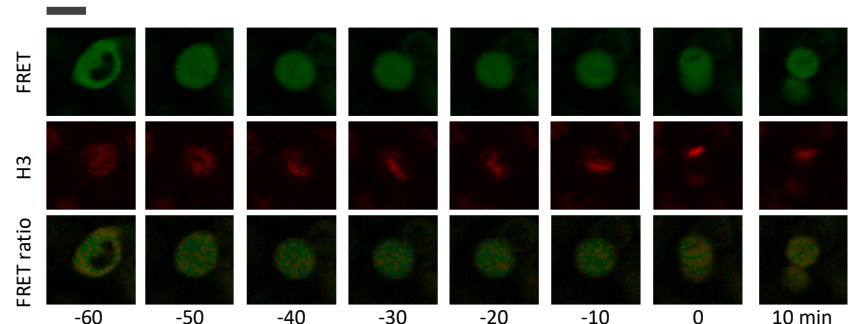

C

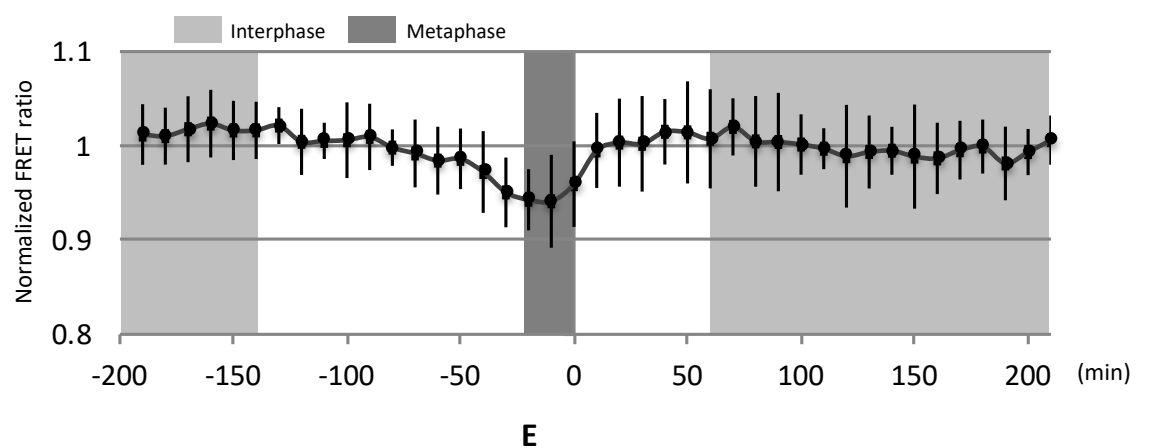

D

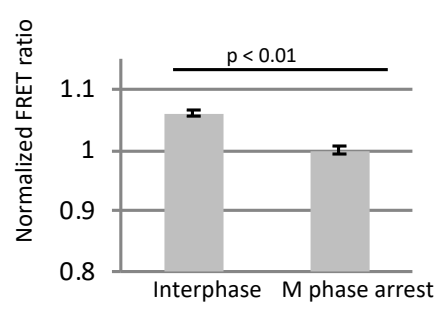

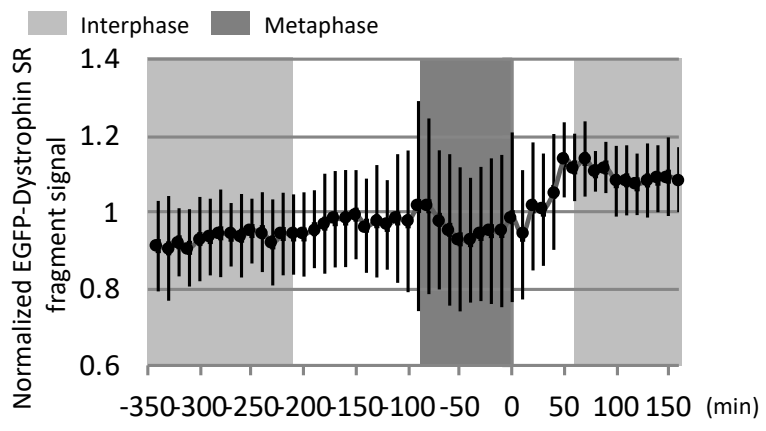

Yamazaki et al. Figure S1 
bioRxiv preprint doi: https://doi.org/10.1101/636407; this version posted June 22, 2019. The copyright holder for this preprint (which was

not certified by peer review) is the author/funder, who has granted bioRxiv a license to display the preprint in perpetuity. It is made available under aCC-BY-NC-ND 4.0 International license.

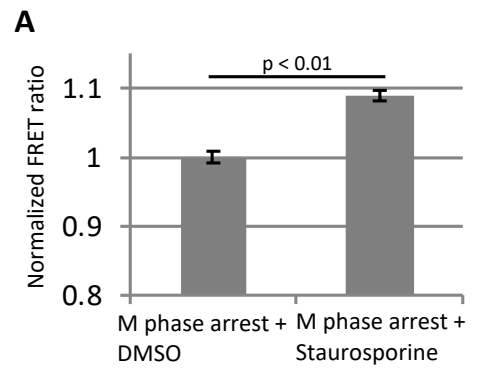

C

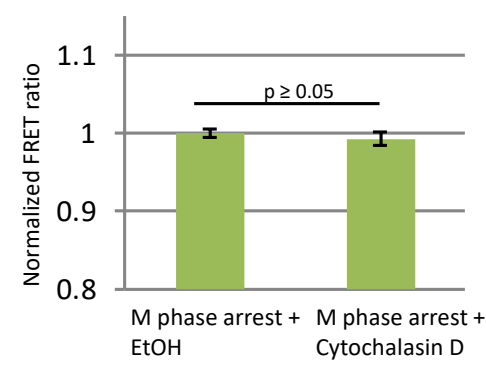

$\mathbf{F}$

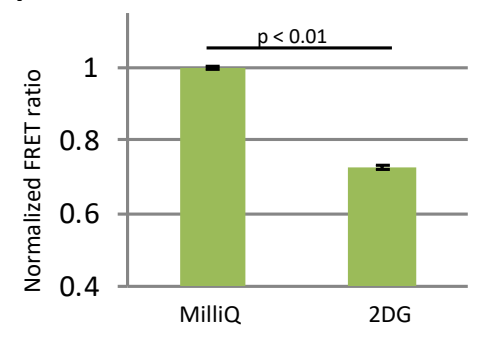

B

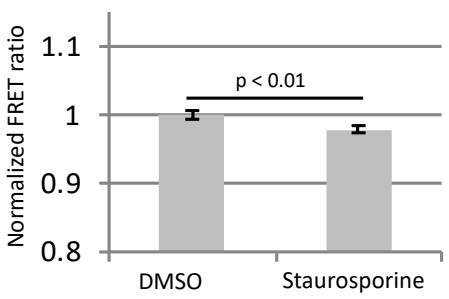

D

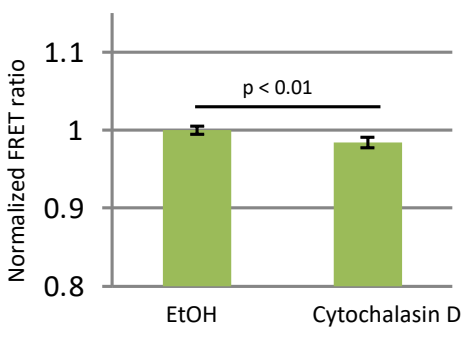

G

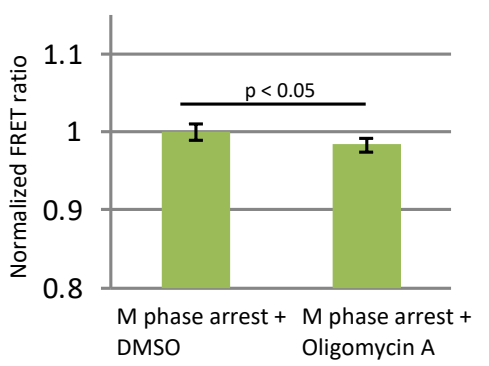

E

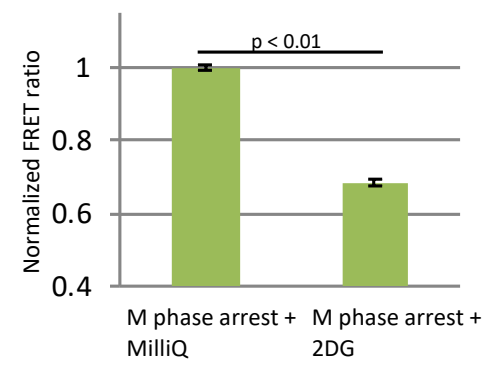

H

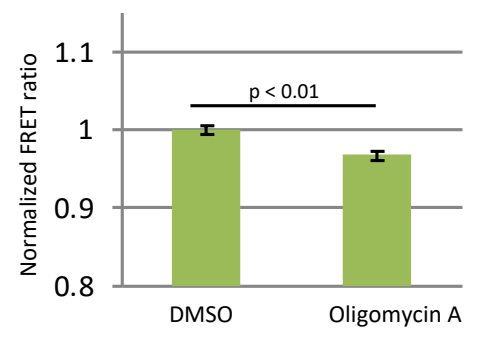

Yamazaki et al. Figure S2 
bioRxiv preprint doi: https://doi.org/10.1101/636407; this version posted June 22, 2019. The copyright holder for this preprint (which was

not certified by peer review) is the author/funder, who has granted bioRxiv a license to display the preprint in perpetuity. It is made available under aCC-BY-NC-ND 4.0 International license.

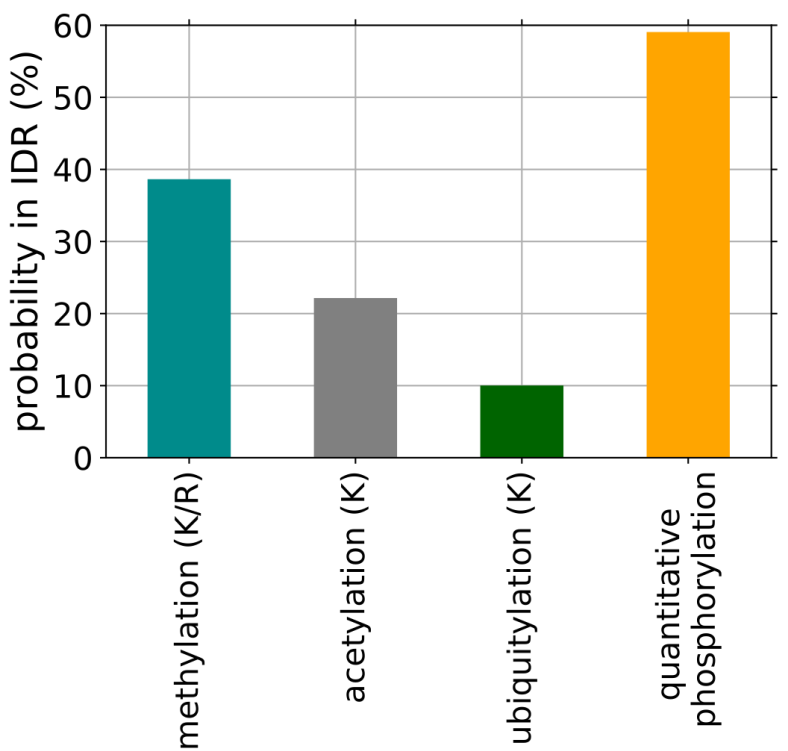

Yamazaki et al. Figure S3 
bioRxiv preprint doi: https://doi.org/10.1101/636407; this version posted June 22, 2019. The copyright holder for this preprint (which was

not certified by peer review) is the author/funder, who has granted bioRxiv a license to display the preprint in perpetuity. It is made available under aCC-BY-NC-ND 4.0 International license.

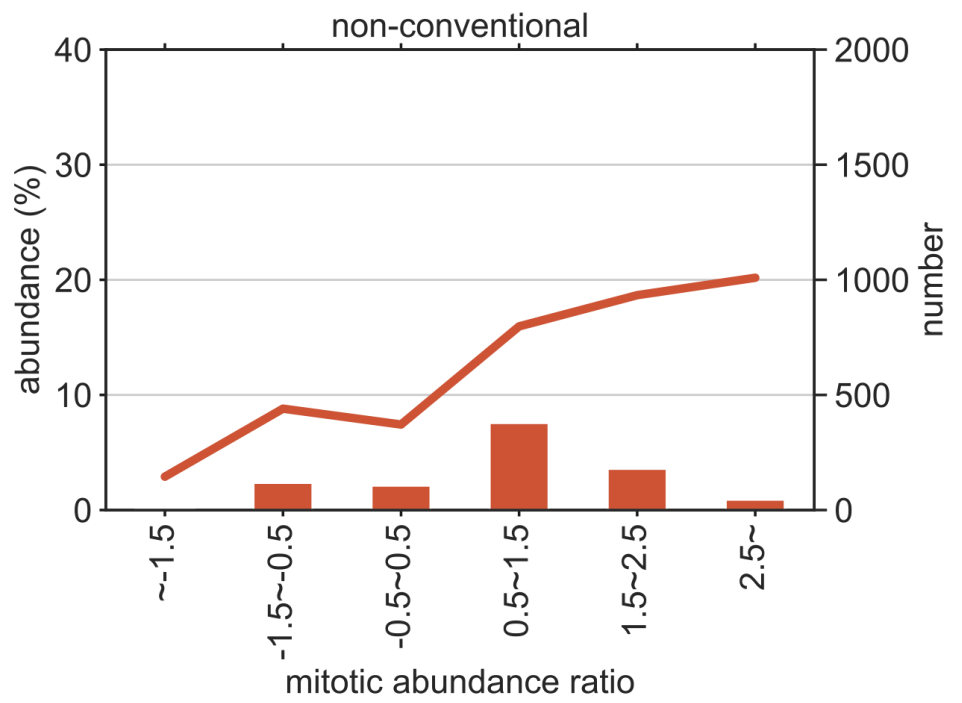

Yamazaki et al. Figure S4 


\section{Supplemental Figure, Table and Legends}

\section{Figure S1.}

Total phosphoprotein amount increases and intracellular ATP level decreases during mitosis. (A) The amount of phosphate on proteins in asynchronous and nocodazole-treated HeLa cells was quantified using pIMAGO and streptavidin HRP conjugate. Dot-blot analysis of the lysate of $\sim 500$ cells is shown. The data points were obtained from three independent experiments, and outliers were eliminated in each experiment based on the inter-quartile range. Significance was assessed using the Mann-Whitney $U$-test. (B, C) Quantification of the cytoplasmic ATP level during mitosis. HeLa cells expressing ATeam and mPlum-histone H3 were observed by live-cell time-lapse imaging. Representative fluorescence images of FRET signal, mPlum signal, and acceptor/donner ratio are shown. Scale bar: $20 \mu \mathrm{m}$ (B). Time 0 was defined as the time chromosomes began to segregate at anaphase onset. The acceptor/donner ratio was quantified in images, normalized to that of cells in interphase, and plotted versus time (C). Data were collected from 16 cells, and each data points corresponds to at least 8 cells. Error bars represents S.D. (D) Comparison of cytoplasmic ATP level between non-treated and nocodazole-treated HeLa cells. HeLa cells expressing ATeam were treated with $2 \mathrm{mM}$ thymidine for $18 \mathrm{~h}$ and released to DMEM with $10 \%$ FBS for $1 \mathrm{~h}$. The cells were then treated with or without $0.2 \mu \mathrm{M}$ nocodazole for $10 \mathrm{~h}$ and observed by confocal fluorescence microscopy. The acceptor/donner ratio was quantified in the obtained images and summarized. Data were collected from more than 100 cells. Values were normalized to those of nocodazole-treated cells. A reduction in signal in mitosis was observed, as was the case in living cells shown in B and C. Error bars represent 95\% CI. Significance was assessed using Welch's $t$-test. (E) The experiment described in Figure S1B and C was performed with EGFP-tagged dystrophin. Data were collected from 13 cells, and each data point corresponds to at least 7 cells. Error bars represent S.D.

\section{Figure S2.}


Protein phosphorylation decreases the intracellular ATP level during mitosis. The experiment described in

600 Figure S1D was performed in the presence of various inhibitors in M-phase-arrested cells (A, C, E, G) and non-synchronized cells (B, D, F, H). For M-phase arrest, HeLa cells were treated with thymidine for 18 h, and after incubation with normal medium for $1 \mathrm{~h}$, the cells were treated with $0.2 \mu \mathrm{M}$ nocodazole for $10 \mathrm{~h} .(\mathrm{A}, \mathrm{B})$

Cells were treated with $1 \mu \mathrm{M}$ staurosporine, a universal inhibitor of kinases for $1 \mathrm{~h}$. (C, D) Cell were treated with $1 \mu \mathrm{M}$ cytochalasin $\mathrm{D}$, an inhibitor of actin polymerization, for $1 \mathrm{~h}$. (E, F) Cells were treated with $10 \mathrm{mM}$

\section{Figure S3.}

Probability of post-translational modifications occurred in IDR. Amino acid residues and its flanking amino comparison, the result of phosphosites obtained in this study is also plotted.

Figure S4. and its percentage (left axis) was plotted against mitotic abundance ratio. 
bioRxiv preprint doi: https://doi.org/10.1101/636407; this version posted June 22, 2019. The copyright holder for this preprint (which was

not certified by peer review) is the author/funder, who has granted bioRxiv a license to display the preprint in perpetuity. It is made available under aCC-BY-NC-ND 4.0 International license.

623 Table S2. A list of proteins which carries NBC motifs and are known to be phosphorylated by AMPK. 